\title{
Nutrition and the development of Osteochondrosis (Dyschondroplasia)
}

\author{
L. B. Jeffcott and C. J. Savage* \\ University of Cambridge, Department of Clinical Veterinary Medicine \\ ${ }^{*}$ Colorado State University, Department of Clinical Sciences, College of Veterinary Medicine, Fort Collins
}

\begin{abstract}
Summary
This paper reviews the effects of overfeeding of foals, particularly with dietary excess of digestible energy and crude protein. The other important nutritional component in the development of osteochondrosis involves mineral imbalance. This may be associated with excessive dietary phosphorus while excess calcium does not appear to induce the condition. There is evidence that a deficiency of copper predisposes to osteochondrosis as well as other forms of development orthopaedic disease. Toxicity due to zinc and cadmium can produce cartilagenous lesions similar to osteochondrosis. It is clear therefore that nutrition plays an important role in the pathogenesis of ostechondrosis, but many other factors (e.g. growth rate, genetics, biomechanics, endocrinological and growth factors) also need to be considered along with diet.
\end{abstract}

keywords: $\quad$ osteochondrosis, nutrition, energy, minerals

\begin{abstract}
Ernährung und die Entwicklung von Osteochondrosen (Dyschondroplasien)
In der Übersicht werden die Effekte einer Überfütterung von Fohlen insbesondere mit verdaulicher Energie und Protein behandelt. Ein anderer wichtiger Komplex bei Entwicklung der Osteochondrosen ist die Imbalanz von Mineralstoffen. In diesem Zusammenhang sind Überschüsse an Phosphor von Bedeutung, während ein Überschuß an Kalzium die Erkrankung nicht zu begünstigen scheint. Bisherige Befunde zeigen, daß auch ein Cu-Mangel für Osteochondrosen und andere Arten orthopädischer Erkrankungen beim wachsenden Tier disponiert. Toxische Mengen von Zink und Kadmium verursachen ähnliche Knorpelschäden, wie sie bei der Osteochondrose beobachtet werden. Insgesamt ist eindeutig, daß die Fütterung eine wichtige Rolle bei der Entstehung von Osteochondrosen spielt, aber viele andere Faktoren (wie Wachstumsgeschwindigkeit, Vererbung, Biomechanik, Endokrinium) in Zusammenhang mit der Ernährung beachtet werden müssen.
\end{abstract}

Schlüsselwörter: Osteochondrose, Ernährung, Energie, Mineralien

\section{Introduction}

The term Developmental Orthopaedic Disease (DOD) is used to describe the numerous disturbances of cartilaginous and skeletal growth in foals and many factors have been implicated in their pathogenesis. Putative nutritional, endocrinological, genetic and biomechanical mechanisms have been focused upon, yet the pathophysiological basis for the primary lesion has not yet been elucidated. One of the most important developmental problems is that referred to as osteochondrosis or dyschondroplasia. The initiating lesion of dyschondroplasia has been defined as a failure of endochondral ossification, with major effects recognized in the zone of hypertrophy of the articular/epiphyseal cartilage complex, affecting the differentiation and maturation of chondrocytes. There is considerable evidence that nutrition plays a major role in the induction of the condition in foals (Jeffcott 1991).

\section{Carbohydrate overload}

Over-nutrition as a predisposing factor in the production of osteochondrosis in the horse was originally based on the work of Hedhammar et al (1974) in the dog. A study by Glade and Belling (1986) who fed young Thoroughbred horses 130\% of the National Research Council (NRC) (1989) recommendations for both digestible energy (DE) and protein appeared to induce lesions of osteochondrosis and physeal dysplasia. Glade, Gupta and Reimers (1984) postulated that the deleterious effects seen in cartilage of horses overfed with carbohydrate were mediated endocrinologically. Thyroxine is required for the maturation of chondrocytes (Glade 1992) and possibly collagen and proteoglycan synthesis. Horses fed high carbohydrate diets may become temporarily hypothyroxemic post-prandially, which could have adverse effects on the cartilage. However, if this were completely accurate it would be expected that young horses fed high amounts of lipid (fat/oil) may be protected and this is not true (Savage, McCarthy and Jeffcott 1993a). A series of controlled experiments showed that diets with $128 \%$ NRC (1989) DE requirements, composed of both carbohydrate and corn oil components were instrumental in the induction of osteochondrosis. Control foals in these experiments were fed a diet based on $100 \%$ of NRC (1989) requirements for weanlings growing at an average daily gain (ADG) of 
In weiterführenden Untersuchungen sollte deshalb den lokalen immunologischen Vorgängen erhöhte Aufmerksamkeit geschenkt werden. Dazu gehört die Untersuchung von Bronchialspülflüssigkeit auf antigenspezifische Antikörper vor und während der Inhalationsversuche. Des weiteren ist eine Differenzierung der im Serum bzw. in anderen, während des Versuchs gewonnenen Körperflüssigkeiten gefundenen Antikörper nach Isotypen einschließlich des IgE erforderlich, um eventuelle Unterschiede in der Beteiligung verschiedener Immunglobulinklassen in unterschiedlichen Stadien des Versuches feststellen zu können. Eine solche Untersuchung war in der vorliegenden Studie noch nicht möglich, da entsprechende isotypspezifische Detektionssysteme noch nicht für Routine- oder umfangreiche Reihenuntersuchungen zur Verfügung standen.

Abschließend lassen sich die Ergebnisse der hier beschriebenen Untersuchungen wie folgt zusammenfassen: Weder durch die orale noch durch die inhalative, sondern nur durch die subkutane Applikation der Antigenpräparationen konnte bei den Versuchspferden eine Immunantwort im Sinne eines signifikanten Titeranstiegs der milben- bzw. schimmelpilzspezifischen Antikörper hervorgerufen werden.

Der Einsatz hygienisch mangelhafter Futtermittel führt demnach keineswegs zwangsläufig zu einer serologisch meßbaren Reaktion auf die enthaltenen Antigene (potentiellen Allergene) oder gar zu einer klinisch faßbaren Schädigung des Tieres. Nach Berichten aus der Praxis sind sowohl Milben als auch Schimmelpilze maßgeblich an der Entstehung eines allergischen Krankheitsgeschehens beteiligt. Derart kontaminierte Futtermittel sollten deshalb schon aus prophylaktischen Gründen nicht an Pferde verfüttert werden. Zur Induktion und Manifestation einer Allergie auf Milben oder Schimmelpilze müssen also weitere Faktoren hinzutreten, die hier experimentell nicht berücksichtigt wurden. Hierfür kommen z.B. genetische Disposition, Infektionen sowie Fehl- oder Mangelernährung in Frage (Thein 1995).

\section{Literatur}

Ahlswede, L. (1995): Pferdegesundheit: Hohe Ansprüche ans Pferdefutter stellen. Reiter und Pferde in Westf. 20 (10), 52-56

Berner, A. (1978): Fünfstufiger Kaskadenimpaktor zur Messung der Massen-Größen-Verteilung von Aerosolen. Chemie-Ing.Tech. 50 (5), 399
Coenen, M. und Kienzle, E. (1992): Beobachtungen zur hygienischen Beschaffenheit von Futtermitteln für Pferde in der tierärztlichen Ernährungsberatung. Pferdeheilkd. , Sonderdruck, Sept. 1992, Hippiatrika Verlagsgesellschaft mbH, Calw, S.209-212

Kamphues, J. und Böhm, K. H. (1990): Tierernährung für Tierärzte aktuelle Fälle: „Krampfkoliken“ bei Pferden nach Fütterung eines verdorbenen Hafers. Dtsch. Tierärztl. Wochenschrift 97, 367-368

Küstermann, S. (1989): Eine Feldstudie zum Hygienestatus von Pferdefuttermitteln unter besonderer Berücksichtigung des Lipopolysaccharidgehaltes. Hannover, Tierärztliche Hochschule, vet. med. Diss.

Lawson, G. H. K., Mc Pherson, E. A., Murphy, J. R., Nicholson, J. M., Wooding, P., Breeze, R. G. und Pirie, H. M. (1979): The presence of precipitating antibodies in the sera of horses with chronic obstructive pulmonary disease (COPD). Equine Vet. J. 11 (3), 172-176

Madelin, T. M., Clarke, A. F. und Mair, T. S. (1991): Prevalence of serum precipitating antibodies in horses to fungal and thermophilic actinomycete antigens: effects of environmental challenge. Equine Vet. J. 23 (4), 247-252

Meyer, H. (1992): Verdorbene Futtermittel. in: Pferdefütterung, Meyer, H. ,Kapitel 2.4., S. 175, 2. Auflage 1992, Verlag Paul Parey Hamburg, Berlin

Petermann, M. (1994): Charakterisierung der in-vivo-Wirkung monoklonaler Rattenantikörper bei Ratten mit experimenteller Rotlaufinfektion. Hannover, Tierärztliche Hochschule, vet. med. Diss.

Raymond, S. L., Curtis, E. F. und Clarke, A. F. (1994): Comparative dust challenges faced by horses when fed alfalfa cubes or hay. Equine Pract. , 16 (10), 42-47

Ripatti, T., Koskela, P., Kotimaa, M., Koskinen, E. und Mäenpää, P. H. (1990): Serum IgG antibody concentrations against environmental microbes in mares and foals during different seasons and effect of stabling practices. Am. J. Vet. Res. 51 (4), 550-555

Schatzmann, U., Gerber, H., Straub, R., Lazary, S. und De Weck A. L. (1973): Applied immunology in chronic pulmonary conditions. Proc. 3rd int. Conf. Equine Infectious Diseases, Paris 1972, 448-457, Verlag Karger, Basel 1973

Thein, P. (1995): Pferdegesundheit: Erkrankungen der Atemwege. Reiter und Pferde in Westf. 20 (4), 52-54

Wilkin, D. R. und Thind, B. B. (1983): Stored product mites detection and loss assessment in animal feed. Proc. of the 3rd Int. Working Conf. on Stored-Product Ent., Manhattan, Kansas (USA), 1983, 608-620

Zeitler, M. H. (1986): Staub-, Keim- und Schadgasgehalte in der Pferdestalluft unter besonderer Berücksichtigung der FLH- (Farmer's lung hay-) Antigene. Tierärztl. Umsch. 41 (11), 839-845

Zmija, G. (1991): Fütterungspraxis bei Galopp- und Trabrennpferden. Hannover, Tierärztliche Hochschule, vet. med. Diss.

Claudia Rade

Institut für Tierernährung

Tierärztliche Hochschule Hannover

Bischofsholer Damm 15

D-30173 Hannover 